\title{
Pengaruh Good Corporate Governance, Profitabilitas, Ukuran Perusahaan, dan Leverage Terhadap Ketepatan Waktu Corporate Internet Reporting (Perusahaan BUMN yang terdaftar Bursa Efek Indonesia Periode 2014- 2018)
}

\author{
Oleh: \\ Megasari Togatorop \\ I Nyoman Agus W, S.E., M.Acc., Ak., CA., CSRS \\ Program Studi Akuntansi Fakultas Ekonomi Universitas Kristen Maranatha Bandung \\ email: aguswijaya.inyoman@gmail.com
}

\begin{abstract}
ABSTRAK
Penelitian ini memiliki tujuan untuk melihat pengaruh dari good corporate governance yang terdiri dari komisaris independen dan komite audit, serta profitabilitas, ukuran perusahaan dan leverage terhadap ketepatan waktu corporate internet reporting.

Penelitian ini memiliki populasi yaitu Badan Usaha Milik Negara yang terdaftar di Bursa Efek Indonesia selama tahun 2014-2018 secara berturut-turut. Penelitian memaanfaatkan sekunder dalam bentuk laporan keuangan yang dipiliah menggunakan metode purposive sampling. Terdapat 32 perusahaan yang memenuhi kriteria sebagai sampel penelitian. Metode analisis yang digunakan untuk menguji hipotesis dalam penelitian ini menggunakan analisis regresi logistik dengan menggunakan program SPSS versi 25.

Hasil penelitian menunjukkan bahwa good corporate governance pada komite audit, profitabilitas dan ukuran perusahaan berpengaruh signifikan terhadap ketepatan waktu corporate internet reporting.

Kata kunci: Good Corporate Governance, Profitabilitas, Ukuran Perusahaan, Leverage dan Ketepatan Waktu Corporate Internet Reporting.

\section{ABSTRACT}

This study aims to examine the effects of good corporate governance consisting of independent commissioners and audit committees, as well as profitability, company size and liverliness of corporate internet reporting.

The population of this study is all state-owned companies listed on the Indonesia Stock Exchange during 2014-2018, respectively. The data used in this study is secondary data and sample selection used a proposal sample method. There are 32 companies that meet the criteria as a research sample. The analytical method used to test the hypotheses in this study uses logistic regression analysis using SPSS version 25.

The results showed that good corporate governance on the audit committee, profitability and company size had a significant effect on the timeliness of corporate internet reporting. As for good corporate governance, the independent commissioners and leverage do not have a significant effect on timeliness of corporate internet reporting.
\end{abstract}

Keywords: Good Corporate Governance, Profitability, Company Size, Leverage and Timeliness of Corporate Internet Reporting. 


\section{PENDAHULUAN}

Di Asia Tenggara, Indonesia dikenal sebagai negara yang memiliki pertumbuhan ekonomi juga peningkatan industri yang pesat. Pertumbuhan tersebut ditandai perusahaan dengan jumlah yang besar yang tercatat di bursa saham di satu negara (Rahma \& Lusiana, 2019). Namun, perlu digarisbawahi jika Indonesia adalah negara yang kompleks juga berisiko dalam menjalankan suatu investasi. Oleh karena itu investasi memiliki kontribusi terhadap pertumbuhan juga pembangunan ekonomi, terlihat berbagai perusahaan yang menjadi emiten di suatu perusahaan, dengan terlibat dalam Bursa Saham (Dewi, Setyad, \& Aziz, 2019). Untuk memberikan indikasi mengenai kesehatan finansialnya, maka para perusahaan yang Go Public melakukan pelaporan keuangan secara rutin. Jika perusahaan menggunakan internet sebagai media untuk memberikan informasi keuangan, maka disebut sebagai Corporate Internet Reporting (CIR). Corporate Internet Reporting (CIR) adalah penyampaian sebagai kewajiban perusahaan menyajikan suatu laporan berupa informasi keuangan dengan menggunakan perangkat seperti internet. Penyajian laporan infomasi keuangan dari suatu perusahaan seperti ini, sebagai metoda modern yang sangat baik dalam mengungkapkan dan menyebarkan berbagai informasi mengenai kondisi keuangan dalam perusahaan (Susanto, 2018). Dalam hal ini di Indonesia berkebijakan mengenai penyajian laporan keuangan melalui media internet secara kelembagaan diatur dengan platform hukum yaitu Keputusan OJK No 29/POJK.04/2016 tentang Laporan Tahunan Emiten atau Perusahaan Publik pasal 15 memuat aturan bahwa perusahaan go public yang memiliki laman (website) diwajibkan untuk mematuhi kebijakan dengan menyajikan dokumen pelaporan keuangan tahunan dalam bentuk laman website, namun untuk perusahaan go public yang tidak/belum mempunyai (website) maksimum setahun setelah berjalannya kebijakan ini, perusahaan go public diharuskan untuk mempunyai laman website yang menampilkan dokumen keuangan perusahaan.

Karenanya, ketepatan waktu untuk mempublikasikan informasi menjadi hal yang sangat penting, karena ketepatan waktu merupakan hal yang penting sebelum keputusan dapat diambil. Bahkan, setelah melebihi tanggal yang ditetapkan, informasi keuangan yang ditampilkan dianggap sudah tidak lagi relevan terhadap pengambilan keputusan investasi. (Rachmadhani, 2018).

Kebutuhan terhadap waktu pelaporan yang sesuai menjadi hal yang dianggap penting oleh profesi akuntansi, ditunjukkan melalui pekerjaan aktivitas 
akuntansi oleh akuntan yang dalam jangka waktu terbatas untuk membuat dan menyampaikan pelaporan akuntansi yang dibuat. Masalah ini berkaitan dengan teori agensi (agency theory) dimana perusahaan memiliki tanggung jawab untuk dapat menjadi saluran informasi yang tepat bagi orang-orang diluar perusahaan untuk dapat mengambil keputusan dalam investasi. Dengan demikian, terdapat tanggung jawab dari para karyawan yang mendapatkan wewenang, terhadap pemilik saham sebagai yang memberi mereka wewenang (Nurfauziah, 2020). Suatu perusahaan dalam membagikan petunjuk informasi yang benar pada pihak eksternal juga dipengaruhi oleh ketepatan waktu pelaporan keuangan sehingga menimbulkan terbentuknya konflik agensi. Konflik agensi yang terjadi timbul lantaran setiap bagian memiliki kepentingannya sendiri, untuk meminimalisir potensi masalah yang dapat terjadi, perusahaan memiliki kewajiban untuk memberikan informasi laporan keuangan tersebut yang akurat juga sesuai dengan waktu yang ditetapkan (Susanto, 2018).

Jika dalam penyajian waktu tertunda semakin lama maka semakin besar peluang adanya insider information yang disampaikan mengenai perusahaan, maka banyak kebijakan mengenai keharusan pelaporan keuangan untuk tepat waktu juga sanksi tersebut menyatakan besarnya tanggung jawab pembuat kebijakan (regulator) dalam menanggapi kasus ketidakpatuhan pelaporan keuangan (Rahma \& Lusiana, 2019). Bursa Efek Indonesia (BEI) telah mempublikasi platform aturan dengan aturan KEP-307/BEJ/07- 2004, membahas mengenai sanksi yang dapat dikenakan pada para emiten, dimana terdapat sanksi yang diberikan jika terjadi keterlambatan proses penyajian informasi laporan keuangan perusahaan yang berkaitan (Rahma \& Lusiana, 2019). Para peneliti yang melakukan penelitian terdahulu dalam melihat pelaporan keuangan tepat waktu, dimana perusahaan tidak terlambat mempublikasikan atau melakukan pelaporan keuangan jika melakukannya sebelum atau pada tanggal 31 Maret. Namun, perusahaan yang melaporkannya setelah tanggal 31 Maret, dianggap terlambat. Sehingga untuk menghitung apakah informasi keuangan perusahaan tepat waktu yaitu memakai variabel dummy, satu (1) untuk perusahaan yang tidak terlambat menyajikan informasi laporan keungan serta nol (0) untuk perusahaan yang terlambat menyajikan laporan keuangan (Isani, 2016).

Para investor pasti ingin menerima informasi dengan cepat, tepat serta akurat. Hal ini tentu menyebabkan suatu perusahaan harus menyampaikan laporan keuangan tersebut melalui media internet dengan tepat waktu. Maka, jika terjadi keterlambatan 
JAFTA - Vol 2 Nomor 1, Oktober (2020)

pelaporan keuangan harus diketahui penyebabnya sehingga perusahaan mencegah terjadinya keterlambatan lain di masa depan juga mendapatkan penyelesaianya. Keterlambatan yang terjadi pada penyampaian laporan finansial tidak hanya karena faktor-faktor eksternal, namun tampaknya ada pihak lain seperti manajemen yang berniat untuk menunda penyajian laporan keuangan tersebut. Disini, menunda penyajian laporan keuangan juga berarti menunda informasi yang akan disampaikan terhadap investor (Isani, 2016).

Para investor pasti ingin menerima informasi dengan cepat, tepat serta akurat. Hal ini tentu menyebabkan suatu perusahaan harus menyampaikan laporan keuangan tersebut melalui media internet dengan tepat waktu. Maka, jika terjadi keterlambatan pelaporan keuangan harus diketahui penyebabnya sehingga perusahaan mencegah terjadinya keterlambatan lain di masa depan juga mendapatkan penyelesaianya. Keterlambatan yang terjadi pada penyampaian laporan finansial tidak hanya karena faktor-faktor eksternal, namun tampaknya ada pihak lain seperti manajemen yang berniat untuk menunda penyajian laporan keuangan tersebut. Disini, menunda penyajian laporan keuangan juga berarti menunda informasi yang akan disampaikan terhadap investor (Isani, 2016).

Peneliti melihat beberapa variabel yang mempengaruhi ketepatan waktu pelaporan. Pertama, ketepatan waktu akan memerlukan penerapan Good Corporate Governance (GCG). GCG yang baik menggambarkan adanya supervisi atau monitoring kinerja manajemen yang akan menghasilkan kinerja yang baik, dan juga mendorong pertanggungjawaban stakeholder yang berdasar pada kerangka peraturan (Susanto, 2018). Dalam perusahaan, penegakan penerapan GCG yang baik dapat dilihat dari dari para komisaris independen, adanya komite audit, kepemilikan institusional yang sesuai, persentase kepemilikan manajerial, juga kualitas audit yang baik (Amelia, 2017). Namun dalam penelitian ini yang digunakan hanyalah komisaris independen juga komite audit.

Selain itu Penerapan $G C G$ dapat memiliki kontribusi terhadap profitabilitas (Rimardhani \& Hidayat, 2016). Profitabilitas menggambarkan kemampuan perusahaan untuk menghasilkan keuntungan (profitabilitas) pada tingkat tertentu, dibandingkan dengan indikator kekuatan perusahaan (Rahma \& Lusiana, 2019). Profitabilitas dalam penelitian ini dilihat dari komponen ROA perusahaan. Jika ROA mengalamai peningkatan atau berada pada taraf tinggi, maka menggambarkan bahwa perusahaan menghasilkan keuntungan, karena return yang dihasilkan semakin besar (Helena Lumban Raja, 2016). Suatu perusahaan yang menunjukkan 
kemampuannya dalam menerbitkan laba dalam jangka waktu tertentu juga disebut dengan profitabilitas yang salah satunya merupakan dimensi kinerja keuangan (Nurfauziah, 2020) .

Faktor lain yang harus dipelajari juga, yang mempunyai pengaruh pada ketetapan waktu corporete internet reporting adalah karakteristik yang perusahaan miliki (Susanto, 2018). Salah satu karakteristik dari indikator yang dipakai dalam penelitian ini merupakan leverage. Laverage menggambarkan sebesar apa aktivitas ekonomi di dalam perusahaan dibiayai oleh hutang dibandingkan modal (equity) sebagai kapasitas perusahaan secara internal. Sebuah perusahaan dianggap baik jika lebih banyak dibiayai oleh sumber internal daripada hutang (Nurfauziah, 2020). Adanya rasio hutang dengan jumlah sangat besar dapat menggambarkan perusahaan terlalu bergantung pada pembiayaan dari bank atau eksternal untuk memastikan bahwa aktivitas perusahaan dibiayai dengan baik (Nurfauziah, 2020).

Faktor lain yang akan berkontribusi adalah ukuran perusahaan yang juga disebut firm size yang dapat mempengaruhi ketepatan waktu (Rahma \& Lusiana, 2019). Firm size/ukuran perusahaan erat kaitannya dengan ketepatan waktu suatu laporan keuangan (Nurfauziah, 2020). Ia mengungkapkan dimana perusahaanperusahaan dengan ukuran yang besar diharapkan mempunyai sumber daya, diharapkan akan dapat mengelola aktivitas akuntansinya dengan baik, sehingga aktivitas penyelesaian laporan-laporan keuangan menjadi lebih cepat dan tepat waktu. (Idawati \& Dewi, 2017). Perusahaan yang memiliki ukuran besar perlu menjaga nama baik perusahaan di mata masyarakat, yang membuat mereka dapat mempercepat aktivitas dan kualitas dari pembuatan laporan keuangan.

Penelitian ini dikembangkan melalui penelitian (Amelia, 2017) dengan studi kasus perusahaan yang berbeda yaitu Badan Usaha Milik Negara (BUMN) juga menambahkan beberapa variabel-variabel lain seperti profitabilitas, ukuran perusahaan serta leverage. Dengan demikian, sesuai dengan yang dijabarkan sebelumnya, membuat peneliti terdorong untuk dapat menyusun Skripsi sebagai laporan penelitian dengan judul "Pengaruh Good Corporate Governance, Profitabilitas, Ukuran Perusahaan juga Laverage Terhadap Ketepatan Waktu Corporate Internet Reporting pada Perusahaan BUMN yang terdaftar di Bursa Efek Indonesia”.

\section{TEORI DAN PENGEMBANGAN HIPOTESIS}

Keefektifan praktik tata kelola korporasi yang baik (good corporate governance) yang telah diterapkan dan 
diawasi oleh dewan komisaris berfungsi sebagai wujud penyelenggaraan GCG (Good Corporate

Governance).

Pembentukan komite audit ini salah satu wujud untuk memperbaiki kinerja internal perusahaan, karena komite audit yang efektif merupakan media dalam menambah keefektifan, tanggung jawab, keterbukaan juga obyektifitas dewan komisaris (Royani, 2019).

Hasil penelitian (Susanto, 2018) menyatakan bahwa good corporate governance tidak berkontribusi secara positif pada ketepatan waktu corporate internet reporting namun hal berbeda yang diungkapkan dalam penelitian (Amelia, 2017) juga (Harnida, 2017) menyatakan bahwa good corporate governance berkontribusi pada ketepatan waktu corporate internet reporting. Dengan demikian good corporate governance meningkatkan ketepatan waktu corporate internet reporting dengan ketentuan yang berlaku. Dari uraian tersebut dikembangkan sebuah hipotesis yakni:

H1: Good corporate governance berpengaruh signifikan pada ketepatan waktu corporate internet reporting.

Profitabilitas menggambarkan kemampuan perusahaan untuk menghasilkan keuntungan, yang ditunjukkan oleh profit yang telah dihasilkan dari penjualan serta pendapatan investasi. Oleh karena itu, semakin besarnya resiko investasi yang diharapkan maka profitabilitas yang diperoleh semakin tinggi (Harnida, 2017).

Suatu perusahaan cenderung akan melakukan penundaan pada pelaporan keuangan jika ditemukan adanya berita yang buruk dari laporan keuangan tersebut mengenai profitabilitasnya, namun perusahaan yang profitabilitasnya tinggi menuntut adanya arus informasi yang pesat, khususnya pada informasi keuangan. Hasil penelitian (Idawati \& Dewi, 2017) menyatakan profitabilitas memiliki kontribusi positif pada ketepatan waktu corporate internet reporting. Dari penjelasan tersebut dikembangkan sebuah hipotesis yakni:

\section{H2: Profitabilitas berpengaruh signifikan pada ketepatan waktu corporate internet reporting.}

Ukuran suatu perusahaan dinilai dari beberapa segi. Besar kecilnya ukuran perusahaan didasarkan pada total nilai aktiva, total penjualan, kapitalisasi pasar, jumlah tenaga kerja juga sebagainya. Semakin besar nilai item-item tersebut maka semakin besar pula ukuran perusahaan itu (Rahma \& Lusiana, 2019).

Besarnya suatu perusahaan akan menunjukkan besarnya informasi yang terkadung di dalamnya, sehingga masyarakat dan perusahaan besar lebih andal juga tentunya akan tepat waktu dalam 
menyampaikan laporan keuangan. Dengan demikian, maka suatu perusahaan besar meningkatkan ketepatan waktu pelaporan keuangan (Idawati \& Dewi, 2017) serta menyatakan bahwa ukuran perusahaan berkontribusi pada ketepatan waktu corporate internet reporting. Dari uraian tersebut dikembangkan sebuah hipotesis yakni:

H3: Ukuran perusahaan berpengaruh signifikan pada ketepatan waktu corporate internet reporting.

Leverage merupakan dimensi yang juga dinilai dalam mengukur kinerja perusahaan. Utang merupakan salah satu komponen terpenting dalam suatu perusahaan, salah satunya yaitu sarana pendanaan. Perusahaan yang memiliki utang yang cukup besar serta kesulitan dalam memenuhi kewajiban merupakan salah satu dari penurunan kinerja (Zuliyana \& Oktarini, 2018).

Leverage merupakan salah satu hutang sumber yang dipergunakan oleh sebuah perusahaan dalam membiayai asetasetnya baik itu dari luar sumber juga modal ataupun ekuitasnya. Rasio leverage merupakan rasio yang juga mendeskripsikan kemampuan perusahaan dalam hal terpenuhinya seluruh kewajibannya. Hasil penelitian (Nurfauziah, 2020) juga menyatakan bahwa leverage berkontribusi secara parsial pada ketepatan corporate internet reporting. Dari uraian tersebut dikembangkan sebuah hipotesis yakni:

H4: Leverage berpengaruh signifikan pada ketepatan waktu corporate internet reporting.

\section{METODE PENELITIAN}

Anggota populasi yang dipilih menjadi sampel penelitian harus memenuhi syarat sebagai berikut:

1. Perusahaan BUMN Publik yang terdaftar juga mempublikasikan laporan keuangan periode tahun 20142018.

2. Perusahaan BUMN Publik yang tidak mengalami rugi periode tahun 20142018.

3. Perusahaan BUMN Publik yang memiliki kelengkapan data juga informasi yang dibutuhkan untuk penelitian.

4. Perusahaan BUMN Publik yang tidak menggunakan mata uang asing.

Variabel penelitian ini merupakan Good Corporate Governance, Profitabilitas, Ukuran Perusahaan juga Leverage (independent variable) yang dianggap berpengaruh terhadap ketepatan waktu Corporate Internet Reporting (dependent variable). Pengujian hipotesis dalam penelitian ini dilakukan menggunakan regresi logistik (logistic regression). 


\section{METODE PENELITIAN}

\section{Uji Endogenitas}

Pelanggaran asumsi ini masuk dalam masalah yang disebut endogenitas. Akibat adanya endogenitas adalah estimator yang diperoleh menjadi bias dan tidak konsisten (bahkan dengan meningkatkan jumlah sample). Permasalahan ini perlu diatasi dengan teknik khusus diantaranya Instrumental Variabel (IV), Two Stage Least Squares (2SLS). Implikasi Endogenitas Untuk menunjukkan bias yang timbul akibat mengestimasi model dengan masalah endogenitas dapat ditunjukkan dengan model pengujian yaitu Two Stage Least Square sebagai berikut:

\begin{tabular}{|c|c|c|c|c|c|c|}
\hline \multicolumn{7}{|c|}{ Coefficients $^{a}$} \\
\hline \multirow{2}{*}{\multicolumn{2}{|c|}{ Model }} & \multicolumn{2}{|c|}{ Unstandardized Coefficients } & \multirow{2}{*}{$\begin{array}{c}\begin{array}{c}\text { Standardized } \\
\text { Coefficients }\end{array} \\
\text { Beta }\end{array}$} & \multirow[t]{2}{*}{$\mathrm{t}$} & \multirow[t]{2}{*}{ Sig. } \\
\hline & & B & Std. Error & & & \\
\hline \multirow{2}{*}{1} & (Constant) & .952 & .037 & & 26.073 & .000 \\
\hline & (log)independent $X^{\prime}$ & -.100 & .627 & -.016 & -.159 & .874 \\
\hline
\end{tabular}

a. Dependent Variable: Corporate Internet Reporting $(Y)$

pengaruh dari matriks korelasi untuk

Dengan menggunakan Two Stage Independen variabel tidak memiliki Least Squares (2SLS), didapat bahwa pengaruh. Dengan demikian, dapat pengaruh nilai logaritimis dari independent variabel secara gabungan tidak memiliki pengaruh terhadap variabel dependen yaitu Corporate Internet Reporting. Didapat model sebagai berikut:

$$
\begin{aligned}
& \mathrm{Y}=\left(X^{\prime}\right)-1 X^{\prime} Y^{\prime} \\
& \mathrm{Y}=0.952-(-0.100)
\end{aligned}
$$

dikatakan bahwa penelitian terbebas dari gejala Endogenitas.

\section{Uji Hipotesis}

Penelitian ini, objek yang dipakai oleh peneliti merupakan entitas perusahaan dalam bentuk Badan Usaha Milik Negara (BUMN) yang telah terdaftar di Bursa Efek Indonesia pada tahun 2014-2018, dimana

Notasi ini berarti bahwa tidak periode pengamatan lima tahun. terdapat gejala endogenitas, dimana adanya

Tabel A

Uji Hosmer Lemeshow

Hosm er and Lem eshow Test

\begin{tabular}{|l|r|r|r|}
\hline Step & Chi-square & df & \multicolumn{1}{c|}{ Sig. } \\
\hline 1 & 3.926 & & 8 \\
\hline
\end{tabular}

Sumber: Hasil Pengolahan SPSS 25 
Nilai Chi-Square mendekati 3.926 dengan nilai signifikan sebesar 0.863 maka terima H0, sehingga dapat disimpulkan bahwa model dapat dianggap fit, terlihat dari tabel bahwa nilai sig sebesar 0.864 yang berarti lebih dari 0,05 (terima H0). Dengan tingkat keyakinan $95 \%$ dapat diyakini bahwa model regresi logistik yang digunakan telah cukup mampu menjelaskan data/sesuai.

\section{Uji Serentak (Simultan)}

Uji serentak adalah uji yang mempunyai fungsi dimana untuk mengetahui signifikansi parameter pada konstanta secara keseluruhan. Dibawah ini adalah tabel yang menggambarkan hasil dari uji serentak dengan Hipotesis :

- $\mathrm{H} 0:: \beta 1=\beta 2=\beta 3 \ldots \beta \mathrm{i}=0$

- H1: Paling tidak ada satu $\beta i \neq 0$

\begin{tabular}{|ll|r|r|rr|}
\multicolumn{7}{|c|}{ Tab el B: Uji Ser entak Param eter Regresi Logistik } \\
Omnibus Tests of Model Coefficients \\
\hline
\end{tabular}

Sumber : Hasil Pengolahan SPSS 25

Diperoleh nilai signifikansi model sebesar 0.003 karena nilai ini lebih kecil dari 5\% maka H0 ditolak sehingga disimpulkan bahwa variabel bebas yang digunakan, secara bersama-sama berpengaruh terhadap variabel terikat yaitu CIR yang merupakan variabel yang diprediksi. Selain itu, ada salah satu variabel prediktor yang berpengaruh.

\section{Analisis Regresi Logistik}

Model regresi logistik digunakan dalam menguji pengaruh Good Corporate Governance terdiri dari komisaris independen juga komite audit, Profitabilitas, Ukuran Perusahaan juga Leverage terhadap ketepatan waktu Corporate Internet Reporting sesuai dengan hipotesis yang dibuat. 
Tabel C: Uji Koefisien Regresi

Variables in the Equation

\begin{tabular}{|rl|r|r|r|r|r|r|}
\hline & \multicolumn{1}{|c|}{ B } & \multicolumn{1}{c|}{ S.E. } & Wald & \multicolumn{1}{c|}{ df } & \multicolumn{1}{c|}{ Sig. } & \multicolumn{1}{c|}{$\operatorname{Exp}(\mathrm{B})$} \\
\hline & 11.813 & 7.869 & 2.254 & 1 & .133 & 134979.366 \\
X1 & 20.777 & 8.087 & 6.600 & 1 & .010 & .000 \\
X2 & 21.619 & 19.715 & 1.202 & 1 & .027 & .000 \\
Step 1 & X3 & .828 & .493 & 2.819 & 1 & .039 & 2.288 \\
& X4 & .608 & .494 & 1.513 & 1 & .219 & 1.836 \\
& X5 & -17.178 & 12.864 & 1.783 & 1 & .182 & .000 \\
\hline
\end{tabular}

a. Variable(s) entered on step 1: X1, X2, X3, X4, X5.

Sumber: Hasil Pengolahan SPSS 25

$$
\begin{aligned}
& \ln (\mathrm{TL} / 1-\mathrm{TL})=\alpha 0+\beta 1 . \mathrm{KI}+\beta 2 . \mathrm{KMA}+\beta 3 . \mathrm{ROA}+\beta 4 . \mathrm{SIZE}+\beta 5 . \mathrm{DER}+\varepsilon \\
& \ln (\mathrm{TL} / 1-\mathrm{TL})=-17,178+11.813 . \mathrm{KI}+20.777 . \mathrm{KMA}+21.619 . \mathrm{ROA}+0.828 \mathrm{Size}+0,608 . \mathrm{DER}+\varepsilon
\end{aligned}
$$

Penjelasan analisis regresi logistik:

1. $\alpha_{0}=-17.178$ artinya jikalau semua variabel bebas sama dengan 0 maka Ketepatan Waktu Corporate Internet Reporting sama dengan -17.178

2. $\beta_{1}=11.813$ artinya jikalau variabel bebas lain tetap serta KI mengalami kenaikan sebesar 1 (satu) poin, akan mengakibatkan Ketepatan Waktu Corporate Internet Reporting akan meningkat sebesar 11.813

3. $\beta_{2}=20.777$ artinya jikalau variabel bebas lain tetap serta KMA mengalami kenaikan sebesar 1 (satu) poin, akan mengakibatkan Ketepatan Waktu Corporate Internet Reporting akan meningkat sebesar 20.777
4. $\quad \beta_{3}=21.619$ artinya jikalau variabel bebas lain tetap serta ROA mengalami kenaikan sebesar 1 (satu) poin, akan mengakibatkan Ketepatan Waktu Corporate Internet Reporting akan meningkat sebesar 21.619

5. $\beta_{4}=0.828$ artinya jikalau variabel bebas lain tetap serta Size mengalami kenaikan sebesar 1 (satu) poin, akan mengakibatkan Ketepatan Waktu Corporate Internet Reporting akan menurun sebesar 0.828

6. $\quad \beta_{5}=0.608$ artinya jikalau variabel bebas lain tetap serta DER mengalami kenaikan sebesar 1 satuan, maka Ketepatan Waktu Corporate Internet Reporting akan meningkat sebesar 0.608 
Uji Satuan (Parsial) dan Exp (B)

Tabel D: Uji T

Variables in the Equation

\begin{tabular}{|cc|c|c|c|c|c|c|}
\hline & & B & S.E. & Wald & df & Sig. & Exp(B) \\
\hline \multirow{6}{*}{ Step 1 $1^{\mathrm{a}}$} & 11.813 & 7.869 & 2.254 & 1 & .133 & 134979.366 \\
& $\mathrm{X} 1$ & 20.777 & 8.087 & 6.600 & 1 & .010 & .000 \\
& $\mathrm{X} 3$ & 21.619 & 19.715 & 1.202 & 1 & .027 & .000 \\
& $\mathrm{X} 4$ & .828 & .493 & 2.819 & 1 & .039 & 2.288 \\
& $\mathrm{X} 5$ & .608 & .494 & 1.513 & 1 & .219 & 1.836 \\
& Constant & -17.178 & 12.864 & 1.783 & 1 & .182 & .000 \\
\hline
\end{tabular}

a. Variable(s) entered on step 1: X1, X2, X3, X4, X5.

Sumber : Hasil Pengolahan SPSS 25

Tabel di atas menunjukkan:

berpengaruh secara signifikan

- $\quad$ Nilai sig. KI sebesar $0,133>0,05$ terhadap CIR

artinya secara partial variabel KI tidak berpengaruh yang signifikan terhadap

- $\quad$ Nilai sig. Size sebesar 0,039>0,05 CIR artinya secara partial variabel Size berpengaruh yang signifikan terhadap

- $\quad$ Nilai sig. KMA sebesar $0,010>0,05$ CIR artinya secara partial variabel KMA

- $\quad$ Nilai sig. DER sebesar 0,219>0,05 berpengaruh yang signifikan terhadap CIR.

- $\quad$ Nilai sig. ROA sebesar $0,027<0,05$ artinya secara partial variabel DER tidak berpengaruhsignifikan terhadap CIR

artinya secara partial variabel ROA

\section{Uji Model Summary}

Tabel E: Uji Koefisien Determinasi Model Summary

\begin{tabular}{|l|c|c|c|}
\hline Step & $\begin{array}{c}-2 \text { Log } \\
\text { likelihood }\end{array}$ & $\begin{array}{c}\text { Cox \& Snell R } \\
\text { Square }\end{array}$ & $\begin{array}{c}\text { Nagelkerke R } \\
\text { Square }\end{array}$ \\
\hline 1 & $21.210^{\mathrm{a}}$ & .172 & .511 \\
\hline
\end{tabular}

Sumber : Hasil Pengolahan SPSS 25

a. Estimation terminated at iteration number 9 because parameter estimates changed by less than .001 .

Nagelkerke $\mathrm{R}$ Square yang NIlai ini menggambarkan besar pengaruh merupakan modifikasi dari cox \& Snell di dari variabel yang diteliti. Nagelkerke mana nilainya bervariasi dari $0-1$, akan menggambarkan besar Pseudo R-Square RSquare sebesar 0.511 atau 51.1\% maka dalam multinominal logistik regression. variabilitas model dapat dijelaskan oleh variabel bebas sebesar $51.1 \%$, sedangkan 
sisanya akan dijelaskan oleh variable lain. Karenanya, secara umum bahwa KI, KMA, ROA, Size, dan DER akan memiliki pengaruh sebesar $51.1 \%$ terhadap CIR.

Secara partial variabel Komisaris Independen tidak memiliki pengaruh secara signifikan terhadap Ketepatan Waktu Corporate Internet Reporting. Secara partial variable Komite Audit memiliki pengaruh signifikan terhadap Ketepatan Waktu Corporate Internet Reporting. Temuan dari uji hipotesis ini sesuai dengan penelitian dengan penulis (Amelia, 2017) yang mengungkapkan bahwa komisaris independen serta komite audit berpengaruh signifikan pada tepatnya waktu pelaporan corporate internet reporting, hal ini diduga berkaitan dengan peran serta tugas dari komisaris independent pada suatu perusahaan, salah satunya yaitu mengawasi kinerja pihak pimpinan perusahaan serta yang juga berhubungan pada peran dari komite audit, yaitu melakukan pengawasan atas proses pepelaporan keuangan, proses audit internal serta proses audit eksternal dengan penulis jasa KAP. Hal ini berarti menyatakan bahwa semakin besar komisaris independent serta komite audit pada suatu perusahaan berarti juga akan semakin tepat waktu pelaporan keuangan yang dilaporkan.

Secara partial variabel Profitabilitas berpengaruh signifikan terhadap Ketepatan Waktu Corporate Internet Reporting. Temuan dari uji hipotesis ini juga berlawanan dengan penelitian dengan penulis (Rahma \& Lusiana, 2019) yang menegaskan bahwa profitabilitas tidak memiliki pengaruh secara signifikan pada tepatnya waktu pelaporan corporate internet reporting, yang berarti bahwa perusahaan yang mempunyai profitabilitas yang tidak baik maka perusahaan akan terlambat dalam menyampaikan pelaporan keuagan, untuk menutupi badnews pada perusahaan dan menentukan pihak eksternal untuk mengakses pelaporan keuangan perusahaan tersebut, dalam mengupayakan pelaporan keuangan yang tepat waktu.

Secara partial variabel Ukuran Perusahaan memiliki pengaruh secara signifikan terhadap Ketepatan Waktu Corporate Internet Reporting. Temuan dari uji hipotesis ini bertentangan dengan penulis (Idawati \& Dewi, 2017) menyatakan tidak terdapat pengaruh secara signifikan antara ukuran perusahaan pada tepatnya waktu pelaporan corporate internet reporting, hal tersebut menunjukkan bahwa ukuran perusahaan baik itu besar maupun kecil tidak memiliki pengaruh secara signiifikan pada tepatnya waktu pelaporan corporate internet reporting. Pada dasarnya tepatnya waktu pelaporan corporate internet reporting dapat memiliki pengaruh dari sejauh mana rasa tanggung jawab suatu perusahaan dalam hal menyampaikan informasi yang berhubungan dengan kondisi perusahaan kepada masyarakat atapun 
pihak-pahak yang memiliki kepentingan pada perusahaan serta bukan pada seberapa kecilnya ukuran perusahaan tersebut.

Secara partial variabel Leverage tidak memiliki pengaruh signifikan pada Tepatnya waktu pelaporan Corporate Internet Reporting. Hasil dari penelitian ini juga mengkonfirmasi penelitian dengan penulis (Purnawanti, 2017) yang juga mengungkapkan bahwa leverage berpengaruh signifikan pada tepatnya waktu pelaporan corporate internet reporting, yang berarti jika perusahaan yang memiliki leverage yang besar juga tidak selamanya menjadi berita yang tidak baik (bad news), tetapi pada perusahaan dengan leverage yang besar juga akan memperoleh kepercayaan dari kreditur dalam hal penggunaan menggunakan dana eksternal (hutang). Perusahaan ini juga memiliki masa depan yang baik dalama hal melunasi hutang jangka panjangnya.

\section{PENUTUP}

Berdasarkan hasil yang diperoleh dari olah data penelitian yang sudah dilakukan terhadap 160 sampel perusahaanperusahaan Badan Usaha Milik Negara (BUMN) yang terdaftar di Bursa Efek Indonesia tahun 2014-2018, ditarik kesimpulan sebagai berikut:

1. Good Corporate Governance secara partial berpengaruh secara signifikan terhadap Ketepatan Waktu Corporate
Internet Reporting. Bedasarkan pengujian uji $\mathrm{T}$, menunjukan nilai sig Komisaris Independen dengan besaran $0,133>0,05$ juga nilai sig Komite Audit dengan besaran 0,010> 0,05 .

2. Profitabilitas secara partial berpengaruh positif terhadap Ketepatan Waktu Corporate Internet Reporting. Bedasarkan pengujian uji $\mathrm{T}$, yang menunjukan nilai sig Profitabilitas dengan besaran 0,027 < 0,05 .

3. Ukuran Perusahaan secara partial berpengaruh signifikan terhadap Ketepatan Waktu Corporate Internet Reporting. Bedasarkan hasil perhitungan statistik $\mathrm{T}$, yang menunjukan nilai sig dengan besaran $0,039>0,05$.

4. Leverage secara partial tidak berpengaruhsignifikan terhadap Ketepatan Waktu Corporate Internet Reporting. Bedasarkan hasil perhitungan statistik $\mathrm{T}$, yang menunjukan nilai sig Leverage dengan besaran 0,219>0,05.

Beberapa saran bagi penelitian selanjutnya yang diharapkan mampu memperbaiki penelitian ini dengan memperhatikan hal-hal berikut ini:

1. Penelitian selanjutnya menambahkan variabel lain yang memberikan pengaruh pada ketepatan waktu 
corporate internet reporting.

Sehingga pada penelitian selanjutnya menentukan faktor yang mempengaruhi ketepatan waktu corporate internet reporting. Faktorfaktor yang memungkinkan dijadikan bahan pertimbangan untuk variabel independen seperti struktur modal, likuiditas, jenis KAP juga variabel lainnya.

2. Bagi peneliti berikutnya melakukan penelitian ini yaitu dengan membandingkan hasil penelitian dengan antar tahun (longitudinal). Sehingga, pada hasil penelitian ini menjadi bahan perbandingan pada perbedaan faktor yang mempengaruhi ketepatan waktu corporate internet reporting.

\section{DAFTAR PUSTAKA}

Agung, S. W., \& Hadinugroho, B. (2019). Analisis Firms Size, Profitabilitas Dan Laverage Terhadap Cash Holding Pada Perusahaan Manufaktur Yang Terdaftar Di BEI Tahun 2016-2018. Seminar Nasional Fakultas Ekonomi Untidar.

Amelia,R. (2017). Pengaruh Mekanisme Corporate Governance Terhadap Ketepatan Waktu Penyampaian Laporan Keuangan Perusahaan. Media Riset Akuntansi, 3(2), 43-65.
Barus, A., \& Norita, N. (2017). Pengaruh Likuiditas, Leverage Dan Ukuran Perusahaan Terhadap Ketepatan Waktu Penyajian Laporan Keuangan (studi Empiris Pada Perusahaan Food Dan Beverages Yang Terdaftar Di Bei Periode 2011-2015). Journal Proceedings of Management, 4(2).

Dewi, N. C., Setyad, D., \& Aziz, M. (2019). Pengaruh Keputusan Investasi Dan Keputusan Pendanaan Terhadap Nilai Perusahaan (Studi Empiris Pada Perusahaan Manufaktur Yang Terdaftar Di Bursa Efek Indonesia Periode 2010-2016). Jurnal Ilmu Manajemen Mulawarman, 3(4).

Fathonah, A. N. (2017). Pengaruh Penerapan Good Corporate Governance Terhadap Financial Distress. Jurnal Ilmiah Akuntansi, 1(2)(2), 133-150.

Ghozali, I. (2005). Aplikasi Analisis Multivariate Dengan Program SPSS Edisi 3. Badan Penerbit Universitas Diponegoro.

Harnida, M. (2017). Pengaruh Mekanisme Corporate Governance Terhadap Ketepatan Waktu Penyampaian Laporan Keuangan: Studi Empiris Pada Perusahaan Publik Yang Terdaftar Di Bursa Efek Indonesia. Jurnal Sains Akuntansi Indonesia, 2(1), 25-36. 
Helena Lumban Raja, D. (2016). Pengaruh

Dewan Komisaris, Komisaris

Independen, Komite Audit Terhadap

Profitabilitas Pada Perusahaan

Sektor Property Dan Real Estate

Yang Terdaftar Di Bursa Efek

Indonesia (BEI) Tahun 2009-2014.

Jurnal Ilmu Manajemen, 4(2).

Hery, S. (2015). Analisis Kinerja Manajemen: Gramedia Widiasarana.

Hery, S., \& Si, M. (2017). Kajian Riset

Akuntansi. In: Penerbit Grasindo, Jakarta.

Idawati, P. D. P., \& Dewi, I. G. A. R. P. (2017). Pengaruh Profitabilitas Dan Ukuran Perusahaan Terhadap Internet Financial Reporting Perusahaan Manufaktur Di Bursa Efek Indonesia. Manajemen STIMI Handayani Denpasar.

Indonesia, I. B. (2016). Manajemen Kesehatan Bank Berbasis Risiko: Gramedia Pustaka Utama. Isani, E. S. (2016). Pengaruh Kepemilikan Institusional dan Manajemen Laba Terhadap Ketepatan

Waktu Pelaporan Keuangan (Studi pada Perusahaan Manufaktur di Bursa Efek Indonesia Periode 2011-2013). Jurnal Ilmiah Mahasiswa FEB, 4(1). Istiana, T., Hasiholan, L. B., \& Fathoni, A. (2018). Analisis Pengaruh Penerapan Struktur Good Corporate Governance Terhadap Kinerja
Perusahaan (Studi Kasus di Perusahaan Rokok yang Terdaftar di Bursa Efek Indonesia). Journal of Management, 4(4).

Kusrinanti, M. A., \& Pamudji, S. (2015).

Pengaruh Karakteristik Keuangan Perusahaan dan Corporate Governance terhadap Ketepatan Waktu Corporate Internet Reporting pada Perusahaan yang Terdaftar di Bursa Efek Indonesia. Fakultas Ekonomika dan Bisnis.

Kusumawardana, Y., \& Haryanto, M. (2019). Analisis Pengaruh Ukuran Perusahaan, Leverage, Kepemmilikan Institusional, Dan Kepemilikan Manajerial Terhadap Manajemen Laba. Diponegoro Journal of Management, 8(2), 148158.

Nurfauziah, F. L. (2020). Pengaruh Profitabilitas, Ukuran Perusahaan, Leverage, dan Reputasi Kantor Akuntan Publik Terhadap Ketepatan Waktu Pelaporan Keuangan Audited. Jurnal Ekonomi, Keuangan dan Bisnis, 1(1), 36-53.

Pham Hanh Song, T., \& Nguyen Duy, T. (2019). The effects of corporate governance mechanisms on the financial leverage-profitability relation: Evidence from Vietnam. Management Research Review, 
43(4), 387-409. doi:10.1108/MRR03-2019-0136

Purnamasari, E. D. (2017). Analisis Pengaruh Leverage Terhadap Profitabilitas Perusahaan Yang Termasuk LQ45 Periode Agustus 2015-Januari 2016 Di Bursa Efek Indonesia. Jurnal Ilmiah Ekonomi Global Masa Kini, 8(1), 41-45.

Purnawanti, Y. (2017). Pengaruh Ukuran Perusahaan, Umur Perusahaan, Profitabilitas, Dan Leverage Terhadap Ketepatan Waktu Pelaporan Keuangan Pada Perusahaan Food And Baverage Yang Terdaftar Di Bursa Efek Indonesia Tahun 2009-2013. Journal Of Accounting, 3(3).

Purnomo, R. A. (2016). Analisis statistik ekonomi dan bisnis dengan SPSS: CV. WADE GROUP Putra, I. M. S., \& Dewayanto, T. (2019). Analisis Pengaruh Good Corporate Governance Index Dan

Kepemilikan Institusional Terhadap Kinerja Perusahaan. Diponegoro Journal Of Accounting, 8(4).

Putri, R. K., \& Muid, D. (2017). Pengaruh Good Corporate Governance Terhadap Kinerja Perusahaan. Diponegoro Journal Of Accounting, 6(3), 84-92.
Qomari, N., Andini, R., \& Raharjo, K. (2016). Faktor-Faktor Yang Mempengaruhi Ketepatan Waktu Corporate Internet Reporting Pada Perusahaan Manufaktur Sektor Industri Food and Baverage Yang Terdaftar Di Bursa Efek Indonesia (Bei) Periode 2007-2013. Journal Of Accounting, 2(2).

Rachmadhani, F. P. (2018). Pengaruh Profitabilitas, Likuiditas, Ukuran Perusahaan, Kualitas Auditor, Dan Kepemilikan Publik Terhadap Ketepatan Waktu Pelaporan Keuangan (Study Pada Perusahaan Manufaktur Periode Tahun 20122016). STIE Perbanas Surabaya.

Rahma, A. A., \& Lusiana, L. (2019). Pengaruh Struktur Modal, Profitabilitas dan Size Perusahaan Terhadap Ketepatan Waktu Pelaporan Keuangan Pada Perusahaan Manufaktur. Jurnal Benefita: Ekonomi Pembangunan, Manajemen Bisnis Akuntansi, 4(2), 210-220.

Rimardhani, H., \& Hidayat, R. R. (2016). Pengaruh Mekanisme Good Corporate Governance Terhadap Profitabilitas Perusahaan (Studi Pada Perusahaan BUMN Yang Terdaftar di BEI Tahun 2012-2014). Jurnal Administrasi Bisnis, 31(1), 167-175. 
Riswan, R., \& Saputri, T. L. (2016). Pengaruh Profitabilitas, Ukuran Perusahaan, Debt to Equity Terhadap Ketepatan Waktu Penyampaian Laporan Keuangan (Studi pada Perusahaan Asuransi yang Terdaftar di BEI). Jurnal Akuntansi dan Keuangan, 6(1).

Royani, I. (2019). Pengaruh Return On Asset, Laverage dan Firm Size terhadap Earning Management pada Perusahaan Industry Perbankan yang terdaftar di Bursa Efek Indonesia Periode 2014-2016. Jurnal Ekonomak, 5(2), 1-14.

Salim, H. (2019). Penelitian Pendidikan: Metode, Pendekatan, dan Jenis: Kencana.

Subagiastra, K., Arizona, I. P. E., \& Mahaputra, I. N. K. A. (2017). Pengaruh Profitabilitas, Kepemilikan Keluarga, dan Good Corporate Governance Terhadap Penghindaran Pajak (Studi pada Perusahaan Manufaktur di Bursa Efek Indonesia). Jurnal ilmiah Agribisnis, 1(2).

Sugiyono, P. (2017). Metode Penelitian Bisnis: Pendekatan Kuantitatif, Kualitatif, Kombinasi, dan Research \& Development. In: CV. Alfabeta: Bandung.
Susanto, A. (2018). Pengaruh Karakterisik Perusahaan Dan Corporate Governance Terhadap Ketetapan Waktu Corporate Internet Reporting. Jurnal Ekonomi dan Bisnis, 5(2), 233-246.

Syofyan, A., \& Herawaty, V. (2019). Pengaruh Good Corporate Governance Terhadap Financial Distress Dengan Kualitas Audit Sebagai Pemoderasinya.

Verawaty, V., Jaya, A. K., \& Suzanna, S. (2018). Determinan Ketepatan Waktu Corporate Internet Reporting Perusahaan Manufaktur yang Terdaftar di Bursa Efek Indonesia. Seminar Hasil Penelitian Vokasi, 1(1), 92-102.

Wijaya, H. (2019). Analisis Data Kualitatif: Sebuah Tinjauan Teori \& Praktik: Sekolah Tinggi Theologia Jaffray.

Yadiati, H. W., Abdulloh Mubarok, S., \& MM, A. (2017). Kualitas Pelapor Keuangan: Kajian Teoretis Dan Empiris (Edisi Pertama): Prenada Media.

Zadeh, F. N., Salehi, M., \& Shabestari, H. (2018). The relationship between corporate governance mechanisms and internet financial reporting in Iran. The International Journal of Business in Society. 
JAFTA - Vol 2 Nomor 1, Oktober (2020)

Zuliyana, M., \& Oktarini, A. O. (2018).

Pengaruh Rasio Profitabilitas Dan

Leverage Terhadap Return Saham

Pada Perusahaan LQ45 Di Bursa

Efek Indonesia (BEI). Akuntanika, 4(2), 80-87. 